\title{
Ecosystem Service: Linking the Ecosystem and the Socioeconomic System
}

\author{
Hua-Xia SHENG ${ }^{a}$ and Luo-Ping ZHANG ${ }^{\text {b,* }}$ \\ College of Environment and Ecology, Xiamen University, Xiamen, R. P. China. \\ ahxsheng@xmu.edu.cn, blpzhang@xmu.edu.cn
}

Keywords: ecosystem services, ecosystem, social-economic systems, decision-making.

\begin{abstract}
The topic of this paper, ecosystem services, is an issue which is on the frontier of interdisciplinary research involving economics and ecology, and also ranks very high on the applied decision-making. This paper reviews the relationship between ecosystem services and ecosystem, ecosystem services and economic system, ecosystem services and decision making, to provide insight and better understanding of ecosystem services. It also discusses the ecosystem services as a bridge to linking the ecosystem and the socioeconomic system in decision-making.
\end{abstract}

\section{Introduction}

Humans have always depended on the services provided by the biosphere and its ecosystems (MA 2003). However, in our increasingly technological society, people give little thought to how dependent they are on the proper functioning of ecosystems and the crucial services for humanity that flow from them (Sekercioglu 2010). This paper reviews the relationship between ecosystem services and ecosystem, ecosystem services and economic system, ecosystem services and decision making. The main objective is discussing the ecosystem services as a bridge to linking the ecosystem and the socioeconomic system in decision-making.

All ecosystems are shaped by people, directly or indirectly and all people, rich or poor, rural or urban, depend on the capacity of ecosystems to generate essential ecosystem services (TEEB 2010). In this sense, people and ecosystems are interdependent social-ecological systems(Elmqvist, Maltby et al. 2010). Ecosystem services are "the conditions and processes through which natural ecosystems, and the species that make them up, sustain and fulfill human life” (Daily 1997).

Recognition of how ecosystems could provide more complex services to mankind date back to at least Plato (c. 400 BC) who understood that deforestation could lead to soil erosion and the drying of springs (Daily 1997). Modern ideas of ecosystem services probably began with Marsh in 1864 when he challenged the idea that Earth's natural resources are unbounded by pointing out changes in soil fertility in the Mediterranean(Wikipedia contributors, Marsh and Lowenthal 1965). Modern expansions of the ecosystem services concept include socio-economic and conservation objectives.

The current interest in combining ecology and economics reflects a new level of concern. Presently ecosystem services are simply defined as the benefits that humans obtain from ecosystems (De Groot 1992, Costanza, d'Arge et al. 1997, Daily 1997, Millennium Ecosystem Assessment 2005, Seppelt, Dormann et al. 2010). Employing the ecosystem service concept is intended to support the development of policies and instruments that integrate social, economic and ecological perspectives. In recent years, this concept has become the paradigm of ecosystem management(Seppelt, Dormann et al. 2010). The ecosystem services concept also integrates economics and ecology among many other disciplines, and is gaining in popularity as a decision making tool (Costanza, d'Arge et al. 1997, Daily 1997, Daily, Polasky et al. 2009, Rea, Davis et al. 2012).

\section{From Ecosystem to Service: Ecosystem Functions and Ecosystem Services}

Ecosystem functions are defined as a subset of the interactions between ecosystem structure and processes that underpin the capacity of an ecosystem to provide goods and services (De Groot, Fisher et al. 2010). It is therefore helpful to distinguish "functions" from the even deeper ecological structures and processes in the sense that the functions represent the potential that ecosystems have 
to deliver a service which in turn depends on ecological structure and processes (TEEB 2010). For example, precipitation (= process) is needed to maintain a viable water cycling (= function) which can be used to provide clean water (= service).

Ecosystem goods (such as food) and services (such as waste assimilation) represent the benefits human populations derive, directly or indirectly, from ecosystem functions (Costanza, d'Arge et al. 1997). However, ecosystem services and functions do not necessarily show a one-to-one correspondence. In some cases a single ecosystem service is the product of two or more ecosystem functions whereas in other cases a single ecosystem function contributes to two or more ecosystem services (Costanza, d'Arge et al. 1997). On the other hand, services are actually conceptualizations of the "useful things" ecosystems "do" for people, directly and indirectly whereby it should be realized that properties of ecological systems that people regard as "useful" may change over time even if the ecological system itself remains in a relatively constant state(De Groot, Fisher et al. 2010).

In short, ecosystem function is the foundation of ecosystem service and ecosystem service directly related to the well-being of human. However, the ecosystem services based on the utility of ecosystems to humans, they are not able to be stand for the ecosystem itself including processes and functions.

\section{Ecosystem Services and Social-economic Systems}

\section{Linking Ecosystem and Economic System}

Comprehensive recognition and scientific evaluation of ecosystem value are fundamental challenge for sustainable development of social-economic system. Ecosystem services valuation (ESV) provided a pathway to link the ecosystem and economic system and tackle such a challenge.

Ecology studies the interactions of organisms with their (natural) environment. Economics studies the interaction of individuals, firms, and government in the (human) economy. However, they are both focus on the interaction and relationship of objects and things. Although it is useful to compare and contrast concepts from economics and ecology to highlight the potential for cross fertilization, the study of ecosystem services requires an explicit integration of this two disciplines(Polasky and Segerson 2009).A major impetus to integrate ecology and economics stems from the recognition of the important role that ecosystems play in providing goods and services that contribute to human welfare and of the impact that human actions have on ecosystems and the flow of services from very local to global scales(Polasky and Segerson 2009).

A review on the approaches to valuation makes it possible to identify two well-differentiated paradigms for valuation to implemented the linking of ecosystem and the socioeconomic system (Pascual, Muradian et al. 2010): biophysical methods, constituted by a variety of biophysical approaches, and preference-based methods, which are more commonly used in economics. The preference -based approach evaluates the total economic value of ecosystem services (Pascual et al. 2010). Methods such as travel cost (Clawson 1959), contingent valuation (Davis 1963) and hedonic pricing (Ridker and Henning 1967) have been proposed for quantifying ESV since the 1960s. These valuation techniques are based, either directly or indirectly, on attempts to estimate the "willingness-to-pay (WTP)" of individuals for ecosystem services (Costanza et al. 1997). However, in most cases, WTP for some newly recognized values, such as non-utility value, could not be derived via market transactions because most of the ecosystem services in question are not traded in actual markets (MA 2003; Liu et al. 2010; TEEB 2010a). For this issue biophysical methods are proposed, they are based on the intrinsic properties of ecosystems by measuring underlying physical parameters (Patterson 1998; Pascual et al. 1010), which flowing from ecosystem to the socioeconomic system, including matter flow analysis (Leontief 1951; Daniels and Moore 2001), ecological footprint (Wackernagel and Yount 1998), energy analysis (Costanza 1980), emergy analysis (Odum 1986; Odum 1996), and eco-exergy analysis (Jørgensen 2010). 


\section{Ecosystem Services in Decision Making}

Human decisions lead to actions that always have profound impacts on ecosystems, causing changes in ecosystem structure, process and function. These changes distinctly result in the changes of ecosystem services and further cause the changes of human well-being. Therefore, comprehensive recognition ecosystem structure, process and function and scientific evaluation of ecosystem services will come about the sustainable and better decision-making.

Daily, Polasky et al. (2009) present a framework for the role that ecosystem services can play in decision making (figure 1). Although the framework is shown as a continuous loop, they start with the "decisions" oval to emphasize the focus. The main aim in understanding and valuing natural capital and ecosystem services is to make better decisions, resulting in better actions relating to the use of land, water, and other elements of natural capital (Daily, Polasky et al. 2009). In the other words, valuation of ecosystem services and tradeoffs helps integrate these services into public decision-making and can ensure the continuity of ecosystems that provide the services (Sekercioglu 2010).

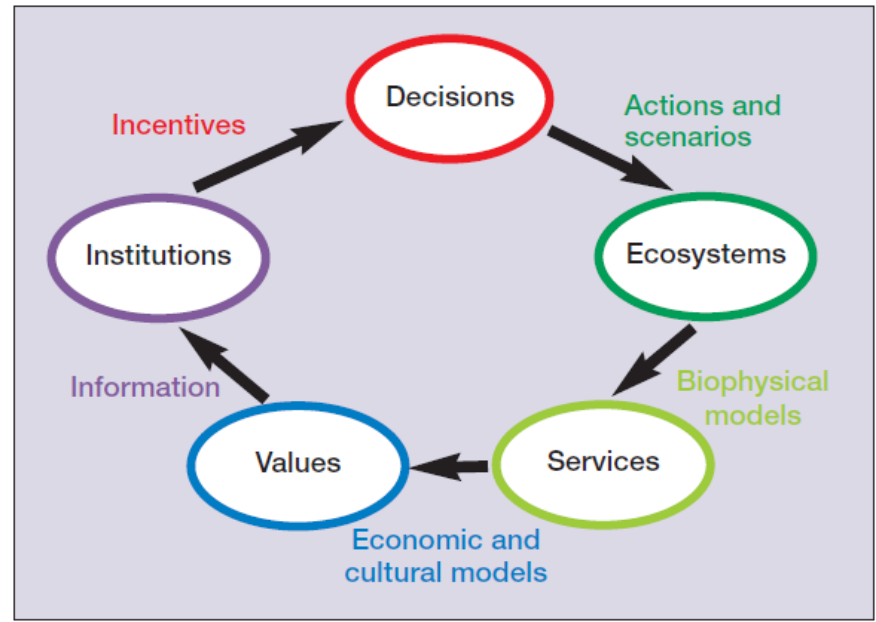

Figure 1: A framework showing how ecosystem services can be integrated into decision making.(Daily, Polasky et al. 2009)

\section{Conclusions}

Although human interest in combining economics and ecological sciences to manage interactions with nature has an extensive history. The proposing of ecosystem services brings a new level of this ecosystem management, prompted by increasing recognition of the scale of the impact of human systems on the ecosystem and the functions and services it provides, especially the establishment of scientific evaluation methods of ecosystem services. With an increasing awareness of the critical importance of ecosystem services for human well-being, many ecologists saw work on ecosystem services as a means of putting ecosystem protection on a more equal footing with other (mainly commercial) interests and hence embraced it as a means of justifying ecosystem protection not just for its own sake but also for its contributions to human welfare(Polasky and Segerson 2009).

This paper reviews the concept and methods of ecosystem services, and the framework for linking the ecosystem and the socioeconomic system. Considered that the concept of ecosystem services links the ecosystem and the socioeconomic system. Although the ecosystem services valuation based on the utility of ecosystems to humans, and cannot involve the full value of ecosystem. It is still an effective and gaining popularity decision tool for protect ecosystem and sustainable development.

\section{References}

[1] Clawson M. Methods of measuring the demand for and value of outdoor recreation. Resources for the Future: Washington D. C., US. 1959. 
[2] Costanza R. Embodied energy and economic valuation. Science. 1980, 210:1219-1224.

[3] Costanza, R., R. d'Arge, R. De Groot, S. Farber, M. Grasso, B. Hannon, K. Limburg, S. Naeem, R. V. O'Neill and J. Paruelo. "The value of the world's ecosystem services and natural capital." Nature. 1997, 387(6630): 253-260.

[4] Daily, G. C. Nature's services: societal dependence on natural ecosystems, Island Pr. 1997.

[5] Daily, G. C., S. Polasky, J. Goldstein, P. M. Kareiva, H. A. Mooney, L. Pejchar, T. H. Ricketts, J. Salzman and R. Shallenberger. "Ecosystem services in decision making: time to deliver." Frontiers in Ecology and the Environment. 2009, 7(1): 21-28.

[6] Daniels P. L., Moore S. Approaches for quantifying the metabolism of physical economies: Part i: Methodological overview. Journal of Industrial Ecology. 2010,5:69-93.

[7] Davis R.K. Recreation planning as an economic problem. Natural Resources Journal. 1964,3:239-249.

[8] De Groot, R. Functions of nature: evaluation of nature in environmental planning, management and decision making, Wolters-Noordhoff BV. 1992.

[9] De Groot, R., B. Fisher, M. Christie, J. Aronson, L. Braat, R. Haines-Young, J. Gowdy, E. Maltby, A. Neuville and S. Polasky Integrating the ecological and economic dimensions in biodiversity and ecosystem service valuation. TEEB Ecological and Economic Foundations. P. Kumar, Earthscan, London. 2010:9-40.

[10]De Groot, R. S., M. A. Wilson and R. M. J. Boumans. "A typology for the classification, description and valuation of ecosystem functions, goods and services." Ecological Economics. 2002,41(3): 393-408.

[11]Elmqvist, T., E. Maltby, T. Barker, M. Mortimer, C. Perrings, J. Aronson, R. De Groot, A. Fitter, G. Mace and J. Norberg. Biodiversity, ecosystems and ecosystem services. TEEB Ecological and Economic Foundations. P. Kumar, Earthscan, London. 2010: 41-111.

[12]Fisher, B., R. K. Turner and P. Morling. "Defining and classifying ecosystem services for decision making." Ecological Economics. 2009,68(3): 643-653.

[13]Jørgensen S. E. Ecosystem services, sustainability and thermodynamic indicators. Ecological Complexity.2010,7:311-313.

[14]Leontief W. W. Input-output economics. Scientific American.1951,185:15-21.

[15]Liu, S., R. Costanza, S. Farber and A. Troy. "Valuing ecosystem services." Annals of the New York Academy of Sciences. 2010,1185(1): 54-78.

[16]Marsh, G. P. and D. Lowenthal. Man and nature, Univ of Washington Pr. 1965.

[17]MA. Ecosystems and human well-being: a framework for assessment. Island Press: Washington, US, 2003.

[18]Millennium Ecosystem Assessment. Ecosystems and human well-being: synthesis, Island Press, Washington D.C. 2005.

[19]Odum H. T. Emergy in ecosystems. In: Ecosystem theory and application. NY: John Wiley. 1986:337-369.

[20]Odum H. T. Environmental Accounting: Emergy and Environmental Decision Making. Wiley New York. 1996.

[21]Patterson M. Commensuration and theories of value in ecological economics. Ecological Economics. 1998,25:105-125. 
[22]Pascual, U., R. Muradian, L. Brander, E. Gómez-Baggethun, B. Martín-López, M. Verma, P. Armsworth, M. Christie, H. Cornelissen, F. Eppink, J. Farley, J. Loomis, L. Pearson, C. Perrings and S. Polasky. The economics of valuing ecosystem services and biodiversity. TEEB Ecological and Economic Foundations. P. Kumar, Earthscan, London. 2010.

[23]Polasky, S. and K. Segerson. Integrating Ecology and Economics in the Study of Ecosystem Services: Some Lessons Learned. Annual Review of Resource Economics. Palo Alto, Annual Reviews. 2009,1: 409-434.

[24]Rapport, D. J. and J. E. Turner. "Economic models in ecology." Science. 1977,195(4276): 367-373.

[25]Rea, A. W., C. Davis, D. A. Evans, B. Heninger and G. van Houtven. "Using Ecosystem Services to Inform Decisions on U.S. Air Quality Standards." Environmental Science \& Technology. 2012.

[26]Ridker R. G., Henning J. A. The determinants of residential property values with special reference to air pollution. The Review of Economics and Statistics. 1967,49:246-257.

[27] Sekercioglu, C. H. Ecosystem functions and services. Conservation biology for all. 2010,1: 45-73.

[28] Seppelt, R., C. F. Dormann, F. V. Eppink, S. Lautenbach and S. Schmidt. "A quantitative review of ecosystem service studies: approaches, shortcomings and the road ahead." Journal of Applied Ecology. 2010,48(3): 630-636.

[29]TEEB. The Economics of Ecosystems and Biodiversity: Ecological and Economic Foundations. London: Earthscan. 2010.

[30]Tilman, D., S. Polasky and C. Lehman. "Diversity, productivity and temporal stability in the economies of humans and nature." Journal of Environmental Economics and Management. 2005,49(3): 405-426.

[31]Wackernagel M., Yount J. D. The ecological footprint: an indicator of progress toward regional sustainability. Environmental Monitoring and Assessment. 1998,51:511-529.

[32]Welsch, H. and J. Kühling. "Using happiness data for environmental valuation: issues and applications." Journal of Economic Surveys. 2009,23(2): 385-406.

[33]Wikipedia contributors. (11 May 2012 19:15 UTC). "Ecosystem services." Retrieved 30 May $2012 \quad 02: 59 \quad$ UTC, from http://en.wikipedia.org/w/index.php?title=Ecosystem_services\&oldid=492057473. 